\title{
The Effects of Selective and Indiscriminate Repression on the 2013 Gezi Park Nonviolent Resistance Campaign
}

\section{Tijen Demirel-Pegg}

\section{Karen Rasler}

\begin{abstract}
We investigate the differential effects of selective and indiscriminate repression on the rate of protest actions during the nonviolent resistance campaign in Gezi Park, Turkey, in 2013. After deriving theoretical expectations about how and why these forms of repression will influence protest actions, we test them with protest event data that were collected from a major local newspaper and subsequently validated through a comparison with two other independent Twitter datasets. Utilizing a Poisson autoregressive estimation model, we find that selective repression, as measured by the number of arrested activists who were detained while they were not demonstrating, decreased the rate of protest actions. Meanwhile, indiscriminate repression, as measured by the frequency of the government's use of lethal and nonlethal violence against protesters during demonstrations, increased the rate of protest actions. Our findings support prior research on the influence of indiscriminate repression on backfire outcomes. They also provide evidence for the impact of selective repression on movement demobilization through the removal of opposition activists. Finally, the targeted arrest strategy of selective repression that was employed in the Gezi campaign has implications for the feasibility of the strategic incapacitation model of protest policing.
\end{abstract}

\section{Published Online in Sociological Perspectives}

This is the authors' manuscript of the article to be published in final edited form at:

Demirel-Pegg, Tijen, and Karen Rasler (2020), "The Effects of Selective and Indiscriminate Repression on the 2013 Gezi Park Nonviolent Resistance Campaign" Sociological Perspectives. https://doi.org/10.1177/0731121420914291. 


\section{INTRODUCTION}

The Gezi Protest Campaign was one of the most significant nonviolent resistance campaigns in Turkey's contemporary history. According to Chenoweth and Stephan's (2011) investigation of over 323 similar campaigns between 1900 and 2006, four critical attributes are linked to their success in achieving either regime change or significant reforms. Three of these four attributes were present in the Gezi Protest Campaign which started in May 2013 and ended by September 2013. With the exception of elite military defections, the campaign was characterized by high levels of dissident participation, a wide cross-section of societal involvement, innovative and diverse types of protest tactics, and the presence of backfire mobilization. Yet, the Gezi campaign fizzled out before protesters could achieve significant reforms. What went wrong? We believe that part of the answer can be found in understanding the repression-dissent relationship during the campaign. To that end, this paper explores a situationallycontext dependent explanation about the differential effects that indiscriminate and selective repression had on the subsequent rates of Gezi protest actions.

When scholars explain how and why protest participation sputtered out in the Gezi campaign, they generally point to the deficiencies of the challengers. Tufekci $(2017, x v i)$ says that the challengers relied too heavily on mobilizing protesters through digital social networks and were unable to build a national organization and leadership that could withstand government repression. Instead, "tactical freeze" took over the movement as protesters were unable to "adjust their tactics, negotiate demands and push for tangible policy changes". Other scholars point to the failure of the movement to present a concrete set of political goals around a single political identity that could connect with other political parties, trade unions and the broader and far larger unorganized working class (Johnson 2015; Özen 2015). Finally, Aytaç et al (2017) argue that the Gezi protesters' inability to attract popular support from 
the political base of the Erdoğan government decreased the probability of elite defections and in turn encouraged the government to use harsh repression that shut down the movement.

Therefore, much of the information about how and why Gezi protests dwindled over time is mostly understood from the challenger's perspective, but there is little emphasis on the state's role in this process. In an effort to rectify this, we examine the state's repressive strategies in bringing about a decline in protest actions which coincided with the end of the campaign. In particular, we focus on the differential effects of indiscriminate and selective repression on the rate of protest actions during the campaign. We aim to show that when the Erdoğan government confronted the dissidents repeatedly with indiscriminate repression, its policy generated an escalation in dissident mobilization or what is commonly referred to as a backfire outcome (Atak and della Porta 2016; Anisin 2016a; Över and Taraktaş 2017). On the other hand, when officials expanded their tactics to include a selective repressive strategy of arrests and detentions that targeted leaders and activists outside of the context of the street protests, they were able to decrease the rate of challenger protest actions significantly. Whether the government's reliance on selective repression brought about the ultimate demobilization of the Gezi campaign is a question that is not addressed in this paper. Instead, our primary theoretical goal is to understand the differential effects of state repression on protest participation in the Gezi case. Nonetheless, our findings will show that the timing in the deceleration of Gezi protest actions with the end of the campaign itself will have important empirical implications for understanding processes of demobilization in general.

We maintain that understanding the role of repression in the Gezi nonviolent resistance campaign is important for three reasons. First, the case reinforces earlier arguments that the concept of repression needs to be disaggregated because types of repression are likely to have different effects on dissident mobilization (Boykoff 2007; Davenport 2007; Chenoweth et al. 2017; Davenport and Inman 2012; Earl 2003; Earl and Soule 2010; Grimm and Harders 2018; Koopmans 1997; White 1989). This 
paper contributes to this argument by demonstrating the varying impacts that the types and targets of selective and indiscriminate repression had on the Gezi protest actions. Second, most of what we know about the effects of repression on dissent is derived from evidence that links individual events of protest across different units of analysis but not in the context of nonviolent resistance campaigns where protest actions are interlinked (Chenoweth et al. 2017, 1951). Therefore, studying the effects of repression on dissent in the Gezi campaign is especially valuable. Finally, the Turkish government's reliance on selective repression is similar to a strategic incapacitation model of protest policing which emerged in the United States after 9/11, wherein authorities targeted certain types of protesters over others, in particular leaders and activists over rank and file participants, in order to control, manage and even diminish the protests (Gillham 2011; Gillham et al. 2013). Since there has been some dispute over the generalizability of this model beyond the U.S. (van Leeuwen et al. 2015), the results in the Gezi case will have important implications for the relevance of this model in other cases.

In the following sections, we first expand our theoretical argument. We then explain our research design and test our hypotheses by using both quantitative and qualitative analyses. Finally, we conclude by discussing the broader implications of our study.

\section{THEORETICAL ARGUMENTS AND HYPOTHESES}

Previous Research on Repression and Dissent

We start our discussion with the definition of two terms: repression and a nonviolent resistance campaign. We define repression as state actions intended to diminish dissident action, collective organization and the mobilization of dissent opinion by inhibiting collective action (Boykoff 2007, 283). In our study, we define nonviolent resistance, such as the Gezi campaign, as a method of struggle that constitutes organized, collective action aimed at preserving or disrupting the status quo (Chenoweth and Stephan 2011; Schock 2005). ${ }^{1}$ According to Chenoweth et al $(2017,194)$, this definition makes a 
distinction between the theoretical and empirical literature on nonviolent resistance and the more general literature on protest and repression which focuses mostly on individual events as opposed to campaigns.

Past research on what Lichbach (1987) has coined the repression-dissent nexus reports that there are a variety of linear and nonlinear linkages within and across different units of analysis. For example, the evidence shows that repression can deter dissident mobilization, can escalate dissident mobilization, can have curvilinear effects on dissident mobilization, can alter protester tactics, may be conditional on regime type or even the type of coercion that is used. The research evidence also varies depending on whether the effects are examined at the macro level (i.e. on overall protest rates), on the meso level (i.e. impacts on social movement organizations), or at the micro level (i.e. impacts on individual dissidents). ${ }^{2}$

For our study, the most relevant research is whether the types and forms of repression influence the rate of protest actions. Unfortunately, there is little consensus among social movement scholars about what a typology of repression should look like despite their many efforts to devise one (Cunningham 2003; Boykoff 2007; Earl et al. 2003; Earl and Soule 2010; Koopmans 1997; Smithey and Kurtz 2018b; della Porta 1996).

Nonetheless, we believe that a "targeting" approach to repression offers a viable approach to tackling the differential effects of repression. ${ }^{3}$ By targeting, we mean that states direct repression against a "range of enemies" in order to neutralize their opposition (Hafez 2003, 75). In this case, there are two types of repressive actions: selective and indiscriminate repression. Selective repression transpires when the government directs its coercion narrowly against leaders and their core activists, while indiscriminate repression is applied against a wider swath of the population that includes supporters, sympathizers and even bystanders (Hafez 2003; Kalyvas 2006). According to Kalyvas (2006), indiscriminate repression involves collective targeting while selective repression is aimed at individuals. 
Probably, the richest area of research on the effects of these two types of repression emerges from the terrorism, rebellion and counter-insurgency fields (Dugan and Chenoweth 2012; Hafez 2003; Jordan 2009; Lindekilde 2014; Kalyvas 2006; Lyall 2009; Rogers 2011; Sullivan 2016b; White 1989). However, much of this evidence does not involve their effects on the rates of protest actions in an ongoing nonviolent resistance campaign (Rogers 2011, 13).

When we turn to studies on nonviolent resistance campaigns, most of the research on this targeting approach is focused on indiscriminate repression where authorities target wide swaths of protesters with violent coercive strategies that generate backfire escalations in dissident mobilization. There are numerous quantitative and qualitative studies that have documented this effect (Aytaç et al. 2018; Anisin 2016b; 2016a; Francisco 2004; O'Brien and Deng 2015; Hess and Martin 2006; Lichbach 1987; Smithey and Kurtz 2018b; Odabaş and Reynolds-Stenson 2018; Schock 2005; Över and Taraktaş 2017; Martin 2007; Nepstad 2011).

Meanwhile, the evidence for the effects of selective repression on nonviolent resistance campaigns is limited to just a few studies that we will discuss in more detail in the following section. ${ }^{4}$ Despite this, the findings from the broader literature on terrorism, civil war and insurgency suggest that coercion against large numbers of challengers and bystanders is likely to escalate dissent while a precise application of coercion is likely to de-escalate it. In the next section, we discuss our theoretical arguments about how and why selective and indiscriminate repression will have differential effects on the rate of protest actions and present our hypotheses that will be tested in the Gezi campaign. 


\section{Why Selective Repression Decreases the Rate of Protest Actions}

A strategy of selective repression that is pertinent to the Gezi campaign can be found within the subfield of protest policing wherein scholars focus on the variation in repertoires of protest control that are utilized by authorities to contain, disrupt and undermine nonviolent resistance campaigns (della Porta and Reiter 1998; McPhail and McCarthy 2005). ${ }^{5}$ In the U.S., after 1999 and especially after 9/11, a strategic incapacitation model became an important strategy employed in the policing of large-scale demonstrations (Noakes et al. 2005; Noakes and Gillham 2006; Gillham and Noakes 2007; Gillham 2011; Starr et al. 2011; Gillham et al. 2013). ${ }^{6}$ This protest policing style relies on a range of tactics that include: the establishment of extensive no-protest zones, the increased deployment of less-lethal weapons, the strategic use of arrests, a reliance on overt and indirect surveillance of transgressive protesters, and the prosecution of these protesters with over-inflated arrest charges. This model reflects a shift toward a preemptive strategy of identifying, marginalizing and controlling transgressive protesters who are deemed to be "social threats". It aims to reduce police uncertainty about how to deal with protesters who deploy tactics that are "unauthorized, unpredictable and confrontational" in the context of informal (leaderless) organizational structures that are based on consensus and/or decentralized decision-making. Throughout the period from the mid-1970s to late 1990s, police were able to reach negotiated agreements with protest leaders about limiting the scale and scope of their demonstrations without preventing them from happening. But, the recent trend since the 2000 s toward less hierarchy and more horizontal structures of protest action has encouraged police to eschew the traditional methods of negotiation to one of "risk management and the prevention" of disorder (Gillham and Noakes 2007, 348).

One of the key tactics of this policy involves the arrests of leaders, activists and organizers so that police can hold them for indefinite periods of time. Police selectively target these "transgressive" protesters because they are perceived to be law breakers and therefore, security threats to public order. 
Their aim is to remove these protesters from demonstrations and to send a message to others that they will be similarly treated. In an effort to identify transgressive protesters, authorities rely on extensive surveillance and intelligence gathering operations during and after the demonstrations (Gillham 2011, 642-45).

Although there is some question about the extent to which the strategic incapacitation model has actually diffused from the U.S. to Europe and elsewhere (della Porta and Tarrow 2012; van Leeuwen et al. 2015), there are important components of the model that were present in the Gezi campaign, namely the government's use of surveillance of the protesters, its forcible removal of protesters from key public spaces (Taksim Square and Gezi Park in Istanbul), its blockade of communal spaces from protesters, and its reliance on a targeted arrest policy aimed at highly visible protest activists. For instance, International Amnesty's (2013) investigation of the role of repression in the Gezi Park protest campaign documents that the Turkish National Police used intelligence-gathering in order to identify and punish activists and to undertake a systematic arrest strategy against protest organizers. The question is whether and how this strategy influenced subsequent Gezi protest behavior.

Theoretically, we maintain that a targeted arrest strategy that is aimed at transgressive protesters, in particular, leaders and visible activists, will decrease the rate of protest actions during an ongoing campaign. This is likely to occur for several reasons.

First, the loss of key leaders discourages protesters about the likelihood of success and sensing futility as well as exhaustion, they will diminish their activism (Earl 2005; Lichbach 1998). Second, the elimination of core activists through arrests undermines the viability of a protest campaign to sustain itself by diminishing the financial resources of its activists who are also subjected to high legal, physical, and psychological costs (Earl 2005). Finally, the absence of leaders and core activists preempts the continued expansion of the mobilization process because it obstructs the capabilities of the protesters to adapt and continue to confront the regime. Without clear leaders, the protesters lose their ability to 
develop contingency plans or counter-tactics in preparation for the next round of repression (Davenport 2015; Sullivan 2016a). This situation is exacerbated if protesters lack strong organizations and networks that can replace leaders quickly (Hafez 2003, 75).

The empirical evidence for the linkages between leadership removal and nonviolent resistance is thin at best, but three studies indicate that the negative relationship has merit. The first study by Bob and Nepstad (2007) on the effects of state-sponsored killings of social movement leaders provides the weakest support. After examining the consequences of political killings of Archbishop Oscar Romero in El Salvador and Ken Saro-Wiwa in Nigeria, they found that the killings had mixed results on dissent depending on several conditional factors. In the case of Nigeria, where harsh repression occurred in the aftermath of a leader killing, the dissidents were shut down. However, in El Salvador, the killing of Archbishop Romero escalated dissent as a result of a divided El Salvadoran government, a societal attachment to martyrdom symbols, and a broad social movement with shared goals and identity. The second study is by Simmons (2012) who provides stronger evidence about the relationship between selective repression and nonviolent dissent. He studied 21 U.S. social movements between 1960 and 1995 and discovered that there were 12 cases of leadership removal via assassinations or arrests resulting in jail time and/or formal sentencing. ${ }^{7}$ His overall regression analysis showed that the effects of leadership removal were associated with a decline in a group's use of large scale nonviolent and violent forms of collective action. The third empirical study is by Sullivan (Sullivan 2016a) who found that repression targeted selectively against the mobilizational actions of challengers in Guatemala between 1975 and 1985 decreased collective dissent such as strikes, protests and targeted attacks. Sullivan defined these mobilizational actions as clandestine organizational meetings, training sessions and recruitment efforts that were essential to planning overt collective forms of dissent. His statistical analysis found that repression targeted against these clandestine actions were indeed associated with decreased collective dissent. 
On the basis of these theoretical arguments and the limited but supportive evidence herein, we hypothesize the following relationship between selective repression, which we will define in this study as a targeted arrest policy, and protest actions in the Gezi campaign.

Hypothesis 1: The implementation of selective repression in the form of a targeted arrest policy will decrease the rate of protest actions.

Why Indiscriminate Repression Increases Protest Actions

We define indiscriminate repression as state actions against dissenters (including any bystanders) during an ongoing nonviolent resistance campaign. The state directs its repression against protesters without regard to individuals' identities or roles in the campaign itself. In the context of the Gezi campaign, indiscriminate repression is operationalized as a protest policing strategy that relies on either or both lethal and non-lethal forms of violence. Lethal forms of repression involve overt violence such as beatings and shootings and even mass arrests so long as they are not part of a selective policing strategy. Non-lethal repression involves the use of teargas, water cannons, pepper spray, tasers, rubber bullets, crowd-control active denial systems (heat ray guns), and any other types of non-deadly munitions (Smithey and Kurtz 2018b, 191). ${ }^{8}$ Unlike selective repression, the targets of indiscriminate repression are diffuse.

Previous research that shows a positive influence of state repression on nonviolent dissent is extensive and this effect is frequently referred to as the "paradox of repression" (Smithey and Kurtz 2018a). ${ }^{9}$ In the context of nonviolent resistance campaigns, much of the evidence about the paradox of repression focuses on how and why government repression has a backfire outcome ${ }^{10}$; in other words, state violence unintentionally escalates rather than diminishes dissident mobilization (Atak and della Porta 2016; Anisin 2016b; 2016a; Brockett 1995; Chenoweth and Stephan 2011; Chenoweth 2018; 
Francisco 2004; Hess and Martin 2006; O'Brien and Deng 2015; Mason and Krane 1989; Ortiz 2007; Över and Taraktaş 2017; Sullivan and Davenport 2017; Davenport et al. 2005).

Why indiscriminate repression results in a backfire outcome can be understood from two types of mechanisms: emotional and informational (Aytaç et al. 2018). The emotional mechanism comes into play when the state's repressive violence is viewed by the public as "unjust, unfair, and disproportionate" (Martin 2007, 205) and generates what Jasper $(1997,106)$ calls a "moral shock or outrage" that galvanizes the mobilization of new protesters. When the protest movement is in its earliest stages, repressive violence should deter bystanders from joining, but the state's disproportionate use of violence can also increase the participation of bystanders whose anger outweighs their fear of protesting (della Porta 2013; Pearlman 2013; Jasper 2014; van Stekelenburg and Klandermans 2013; van Zomeren 2013). For this emotional response to occur, protesters must be able to communicate the state's repressive violence to receptive audiences (Martin 2007, 206). This communication can be accomplished through a variety of social and media networks, but the evidence of the state's violence must be transmitted to a wide variety of people. ${ }^{11}$

Meanwhile, the informational mechanism is rooted in how indiscriminate repression changes bystanders' beliefs and actions about the viability of engaging in anti-government protests. Cascade models of mobilization depicted by Lohmann (1994), Granovetter (1978), DeNardo (1985), Kuran (1991), and Opp (1994) are all based on the argument that people's beliefs about the relative strength and weakness of the government shifts as a consequence of its heavy-handed tactics against demonstrators. The repression is perceived to be not only illegitimate but also an indicator that the opposition is much stronger than people had believed. In this case, the general population withdraws it support from the government in the hopes of achieving genuine reforms (Aytaç et al. 2018, 128).

In the case of the Gezi campaign, Aytaç et al (2018) conducted in-depth interviews of Istanbul residents in 2015 in order to tease out which of these two types of mechanisms motivated individuals to 
join the Gezi protests. Initial surveys indicated that at least half of those citizens participating in the Gezi protests in Istanbul were indeed motivated to join the movement after seeing police brutality. A second line of evidence emerged from a field experiment wherein Aytaç et al (2018) interviewed 833 adult Istanbul residents in order to assess their reactions to photographs that would mimic the severity of police actions used in the Gezi protests. Their sophisticated experimental design which included a placebo group provided evidence that an emotions-based explanation (repression induced anger and anger encouraged collective action) was a stronger factor than whether individuals' beliefs about the government's viability had changed.

Aytaç et al's (2018) research is also supported by Över and Taraktaş's (2017) ethnographic field interviews of 60 protest participants and a survey analysis of 1,352 Gezi protesters. Their findings show that an overwhelming majority of people went to Gezi Park in order to protest disproportionate police violence against the early Gezi protesters. The backfire outcome was due to people's perception that the police violence against these early protesters was unjust, especially since their actions and their movement goals were "innocent". Moreover, protesters, through their joint participation, changed their perceptions of each other as allies despite their pre-existing political and social divisions. Hence, the emotional effects of disproportionate state repression on bystanders generated the first backfire outcome, and the subsequent phases of increased protest participation was sustained by the solidarity and trust that emerged among the protesters as they engaged in collective action.

Finally, Anisin's (2016a) analysis of the 2013 Gezi protests follows similar lines of previous evidence. He finds that the disproportionate use of state repression generated a backfire outcome due to the moral and public outrage by protesters in combination with viral diffusion, government cover-up attempts and the coordination of this information by protesters through social media. All of these factors contributed to the emergence of a mass anti-government movement. 
Therefore, on the basis of both the theoretical arguments and the empirical findings in the Gezi case, we put forth the following hypothesis.

Hypothesis 2: The implementation of indiscriminate repression will increase the rate of protest actions.

\section{RESEARCH DESIGN}

Why Study the Gezi Park Nonviolent Resistance Campaign?

The Gezi campaign is an excellent case to assess our theoretical argument for two reasons.

First, the campaign was not only unprecedented in Turkey's history, but it was also relatively short but still long enough to observe waves of escalating and deescalating protest actions. What began as a localized protest about the destruction of a public park in Istanbul quickly transformed into a national movement that triggered anti-government demonstrations all across the nation. The public park demolition turned into a broader symbol of resistance from the growing authoritarianism and socially interventionist rule of Prime Minister Erdoğan's AKP-led government. Anti-government demonstrations occurred in more than 79 cities in Turkey and according to surveys, they involved more than 12.1 percent of the population above the age of 18 years, which was estimated at the time to be approximately 50 million (Gürcan and Peker 2015, 8).

Second, an examination of the Gezi Park campaign as a single case study has some advantages over cross-national studies. For instance, a sole focus on the Gezi campaign makes it possible to control for many aspects of the political and social environment which Earl and Soule (2010) say yields a "theoretically homogenous" analysis. In other words, we avoid the potential complications of comparing different forms of repression across different nations and social movements, a hazard that Koopmans (1997) and Davenport (2007) argue account for the discrepant findings in the repressiondissent literature. Koopmans (1997) and Davenport (2007) also argue that disaggregated data below the 
subnational level makes it easier to compare the effects of different types of repression in the context of a single nonviolent resistance campaign, thus providing a precise focus on time, place and behavior. ${ }^{12}$

Data

We use original data collected by the authors from Cumhuriyet, a national daily newspaper in Turkey to illustrate the interactive dynamics of the Gezi protest campaign. The dataset covers both nonviolent and violent forms of protest (such as demonstrations, strikes, and clashes with the police) and government responses (such as the use of teargas, the imposition of bans, and arrests). Events were coded for the date, actor, location, target, number of participants, number of injured and number of deaths, and any events that lacked this information were excluded from the data set. In total, 1,416 events were hand coded based on a list of events found in Krain's (2000) scale of repression, accommodation and dissent actions in post-revolutionary states and Moore and Lindstrom's (1996) Violent International Conflict Data Project. ${ }^{13}$ The data were aggregated in daily intervals to capture the rapidly evolving dynamics of the campaign.

In an effort to provide evidence for the validity of our data, we compared the frequency of our protest events data with the frequency of Twitter protest data collected by two different scholars, one of which was produced by Budak and Watts (2015) and the other by Öztürkcan et al. (2017). Figure 1 plots these three data series and it shows that our events data follow similar trends as those produced by the Twitter protest data. Unlike our data, which is based on protest events, Budak and Watts (2015) and Öztürkcan et al.'s (2017) data are based on the number of tweets that reflect key terms such as "Gezi locations", "resistance", and "uprising" hashtags over the course of the protest campaign. As Figure 1 shows, the trend of our protest actions data correlates closely with the trends associated with the Twitter data, increasing the validity of our data.

/ Figure 1 about here / 


\section{Variables}

The rate of protest actions, the dependent variable, is the total daily number of nonviolent and violent forms of collective actions including demonstrations, strikes, boycotts, violent clashes with the police, standing man protests, and park forums. ${ }^{14}$

Our first independent variable, selective repression, is operationalized as the total number of activists who were arrested when they were not engaged in street demonstrations or what we call "offsite targeted arrests". ${ }^{15}$ We make a distinction between these arrests and "onsite arrests", where activists were detained in locations where they were participating in demonstrations. We argue that onsite arrests will more likely reflect a reactive or indiscriminate policy, while offsite targeted arrests will reflect a selective policy designed to remove key leaders and activists. For instance, in the Gezi case, it has been documented that Turkish police used surveillance techniques to identify activists, usually through their cell phone records or photographic evidence of their participation in the demonstrations (Amnesty International 2013, 43). Subsequently, in a series of raids and police operations across Turkey, the police arrested, indefinitely detained, and interrogated key opposition groups such as university students, leftist party adherents, and Taksim Solidarity Platform members, who originated the protests to stop the Gezi Park destruction. Frequently, detainees faced criminal charges for participating and/or acting on behalf of an illegal organization, or attempting to overthrow the regime, or damaging public property (Amnesty International 2013, 42).

For our empirical analysis, we transform our measure of offsite targeted arrests with a logit transformation of the ratio of the total daily number of targeted offsite arrests over total arrests (which is comprised of both onsite arrests and offsite targeted arrests). This ratio measure captures the government's reliance on offsite targeted arrests relative to onsite arrests more accurately than a simple count measure of offsite targeted arrest events. ${ }^{16}$ The plot of the logit transformation of our ratio 
measure in Figure 2 illustrates the degree to which the Turkish government relied on offsite targeted arrests vs. onsite arrests throughout the protest campaign. The troughs in the series that are below the value of zero until June 25, 2013 (the date of the Gezi park clearing) indicate that the government relied heavily on onsite arrests during the first three weeks of the nonviolent resistance campaign. Meanwhile, the peaks above the value of zero after June 25, 2013 show that the government relied more extensively on offsite targeted arrests in the later period of the campaign. However, this measure is a bit misleading in that it suggests that the targeted arrest campaign began on June $25^{\text {th }}$ after the Gezi protest actions began declining (see Figure 1). An examination of the nonproportional data for targeted arrests in the second plot of figure 2 shows that the increase in targeted arrests started on June 18, 2013 which also coincides with the beginning of the decline in these protest actions. Therefore, the proportional values for offsite arrests (Plot A in figure 2) provide a good overall picture of the government's heavier reliance on offsite arrests during the full protest campaign, but they do not pinpoint the actual onset of the targeted arrest policy itself. This date is better reflected in the frequency data of onsite targeted arrests (see Plot B in figure 2) as well as the reports in the historical record (International Amnesty 2013).

\section{/ Figure 2 about here /}

Indiscriminate repression, our second independent variable, is operationalized as the total daily number of lethal and nonlethal repressive actions used by the police to disperse the protesters. Such actions included the use of road blockades, water cannons, teargassing, and rubber bullets. The minimum values of the indiscriminate repression variable indicate days when authorities used little to no dispersive tactics against the protesters, while the maximum values reflect days when they relied heavily on dispersive tactics. The measure shows that the government used indiscriminate forms of repression throughout the nonviolent resistance campaign, but most heavily during the early part of the campaign from May 28 to June 16, 2013. 
Control variables: government concessions to protesters and foreign support for protesters. We introduce government concessions into our regression equations in order to control for the effects that they might have on protest actions. Previous scholars have argued that concessions and/or accommodations to protesters' demands are likely to decrease protest actions as a result of the government's successful efforts in coopting some if not most of the activists (Piven and Cloward 1977). Government concessions may also breakdown the unity of protest movements as moderate and radical activists argue about how to respond to them (Tarrow 1989). If concessions are targeted at coopting moderates at the expense of radical factions, moderates may have strong incentives to discontinue their protest actions. The overall effect would be a decline in protest actions. We measure government concessions as the total daily number of government accommodations to the protesters. Such actions include negotiations, meeting with protesters, and allowing activists to protest in Gezi Park. A plot of the frequency of these concessions in Appendix A-1 shows that the Turkish government made minor concessions during the first two weeks of the campaign, well before the implementation of its targeted arrests strategy and a decline in protest actions.

Foreign support to protesters, our second control variable, is introduced because such international support has been associated with increased protest actions. Previous empirical research shows that positive support for the protesters' claims through the presence of public endorsements, criticisms of government repression, international sanctions and consumer boycotts on behalf of protesters, the divestment or disinvestment of resources from the economy, the emergence of transnational advocacy networks, and the extension of material support to the protesters have been associated with sustaining social movements and their protest actions (Keck and Sikkink 1998; Murdie and Bhasin 2011; Schock 2005). We operationalize foreign support to protesters as the total daily score of support that protesters received from foreign governments, and intergovernmental and nongovernmental organizations. In the Gezi campaign, such foreign support was limited to diplomatic 
communications, public statements, and press conferences from a variety of actors, including International Amnesty, the EU, NATO and other international leaders. The plot of this variable in Appendix A-2 shows that foreign support for the Gezi protesters occurred more frequently during the first four weeks of the campaign, including the first phases of the implementation of the targeted arrests strategy.

Methodology

We estimate two Poisson autoregressive (PAR) models of order $(p)$ in order to examine the differential effects of the Turkish government's use of selective and indiscriminate repression on the rate of protest actions during the Gezi campaign. PAR is a count model that is able to take into account the dynamic processes of event count data. For instance, the number of events observed at time $t$ depends on the number of events observed at some previous time period, such as $t-1$. If we fail to account for this time-dependency, our estimates of our coefficients would be inefficient (Brandt and Williams 2001). Our data are particularly suitable for a PAR analysis for two reasons. First, our data are ordered in time and we expect that past observations will influence future values; and second, our dependent variable is a rate measure of protest actions and is likely to exhibit cyclical and shortmemoried processes that are mean reverting (Brandt and Williams 2001). The estimated autocorrelation function (ACF) of our protest rate series in Figure 3 shows that there is indeed time dependency in the event counts of our protest series. In particular, there is autocorrelation in the first three lags, indicating that the time series process generating our dependent variable has a short-term memory.

In light of the appropriateness of the PAR time series count models for our data, we estimate two separate regression models. Model 1 examines the effects of selective and indiscriminate repression alone, while Model 2 incorporates concessions and foreign support to protesters as control 
variables. We estimate two models due to the small sample size of our data and the concern for losing degrees of freedom that would occur in a single model. Nonetheless, the estimation results will be able to tell us whether the effects of selective and indiscriminate repression on the rate of protest actions are consistent across both models.

\section{FINDINGS}

The quantitative findings show that selective repression was associated with a significant decrease in the rate of protest actions over the course of the Gezi campaign. ${ }^{17}$ As Table 1 indicates, the coefficient of offsite targeted arrests is negative and statistically significant $(p<.05)$ in Models 1 and 2 , confirming our first hypothesis that selective repression would decrease the rate of Gezi protest actions. As predicted, indiscriminate repression, measured as the number of times that the government used lethal and non-lethal tactics, is associated with a positive increase in the rate of protest actions (see Model 1). This positive and statistically significant effect of indiscriminate repression $(p<.01)$ also holds across Model 2 which in combination with Model 1 supports our second hypothesis that indiscriminate repression would increase the rate of protest actions.

/ Table 1 about here /

In regard to our first control variable, concessions, Model 2 shows that it failed to have a statistically significant effect on protest rates. This result is not surprising given the fact that the Erdoğan government failed to offer any major concessions throughout the campaign. As for our second control variable, foreign support to protesters, Model 2 shows that the coefficient is negative but statistically insignificant which goes against our theoretical expectation that foreign support would have a positive influence on the rate of protest actions, especially since the data show that foreign support was high during the first weeks of the Gezi campaign when protest actions were at their highest levels. Despite this pattern, we do not have confidence in this negative result given the small sample size of our 
data and the low significance level of the coefficient itself. ${ }^{18}$ On a substantive level, foreign support to Gezi protesters was largely symbolic without posing serious threats or consequences to the Erdoğan government. Overall, the evidence in Models 1 and 2 show that indiscriminate and selective repression had positive effects as hypothesized with similar coefficient sizes and significance levels. We also estimated robustness checks of our results with several three additional models, one of which was an interventional analysis and the remaining two with different forecasting models (See Appendix B). These additional checks support the PAR estimation results in Table 1.

On a substantive level, our findings are also supported by qualitative analyses advanced by other scholars who studied the Gezi protest campaign. Such analyses showed that during the first three weeks of the protest campaign, the interactions between the government and the opposition settled into a consistent pattern: protesters used disruptive and confrontational tactics like sit-ins, strikes and demonstrations while the government responded with indiscriminate repression, using water cannons, teargas, rubber bullets and road blockades (Atak 2017). This heavy use of indiscriminate repression was the result of Turkey's prior commitment to a "militarized" policing strategy after riots and strikes occurred there in the 1980s and 1990s. Atak (2017) explains that the lines between policing and warmaking blurred by the end of the 1990s after "special or support squads" of riot police who were trained with paramilitary skills were integrated into the larger police force. In addition, military troops were delegated to defuse urban mass demonstrations before they could spread to other areas of the country. Besides reorganizing its policing capabilities, the government also bought and stockpiled large numbers of less-lethal weapons for future use. For instance, between 2000 and 2012, Turkey imported 628 tons of teargas, bought 39 water cannons between 2006 and 2008, accrued 125 rifle launchers for firing paint, teargas and other projectiles into demonstrating crowds, and since 2010 , continued to invest heavily in water cannons, teargas, and even electromagnetic ray guns (Atak 2017, 700). 
Finally, Atak (2017) maintains that the government's initial reliance on indiscriminate repression was also rooted in the historical negative outlook that police had toward protesters as criminals and even terrorists. This bias explains why police pursued a "zero tolerance" approach to street level protests during the Gezi campaign (Atak and della Porta 2016). Thus, it was predictable that fierce police intervention in the Gezi encampment in the initial stages would galvanize masses of people across the country to join the Gezi protesters. Field interviews of participants would later reveal that this backfire outcome was directly attributable to the government's use of indiscriminate repression (Atak and della Porta 2016; Anisin 2016a; Över and Taraktaş 2017; Aytaç et al. 2018).

Meanwhile, another escalation of protest action occurred three weeks later when on June 15, 2013, the Turkish police forcibly cleared and closed the Gezi Park encampment indefinitely. On June $16^{\text {th }}$, thousands of people across the country returned to street protests. On June $17^{\text {th }}$, a broad coalition of unions, including labor, civil servants, doctors, dentist, and architects, organized a nation-wide strike. At this time, dissidents innovated new forms of standing man protests, as the police continued to clash with protesters in the major urban areas of the country (Gürcan and Peker 2015).

Starting on June $18^{\text {th }}$, police, while still relying on indiscriminate repression at various demonstration sites, initiated a wave of offsite arrests especially in Istanbul and Ankara, the hotbeds of the urban protests. They detained not only members and leaders of social and political networks for arrests but also their networks of support, including their attorneys and medical personnel who treated their injuries. Later, on July $8^{\text {th }}$, the police arrested 48 members of the Taksim Solidarity Platform in advance of their efforts to participate in a protest planned at Gezi Park (Amnesty International 2013, 4950). In sum, the government sent a clear signal to activists and potential followers that they were vulnerable since it had the ability to identify, find, arrest, and penalize them harshly.

We believe that these depictions of protest and repression by other scholarly studies supports our quantitative evidence that indiscriminate and selective repression had differential effects on the 
rate of protest actions during the Gezi campaign. On a theoretical level, our results reinforce the theoretical and empirical research found in repression-dissent studies regarding the backfire consequences of indiscriminate repression. Our findings support and add to the much smaller number of studies that have found negative influences of selective repression on protest actions. Our findings also suggest that selective repression may play an important role in understanding the demobilization process of protest campaigns. Although this was not a central question of our study, we believe that our findings indicate that both the challenger and the government's perspectives, strategies and tactics should be considered in understanding how and why demobilization occurs.

\section{CONCLUSION}

This study shows the differential effects of indiscriminate and selective repression on the rate of protest actions in the Gezi Park nonviolent resistance campaign. The protest data, the quantitative evidence and the qualitative depictions by other scholars all reinforce the support of our two hypotheses. Namely, indiscriminate repression is likely to generate an escalation, if not a backfire outcome, of protest actions. And, a systematic policy of selective repression that aims to eliminate activists, leaders and their support networks can be especially effective in reducing protest actions. The bottom line here is that policing strategies based on either type of repression will have significant consequences for the containment of nonviolent resistance.

There are several theoretical implications of our findings. First, our analysis is one of the few studies on nonviolent resistance where selective repression is a key independent variable. Typical studies of selective repression are concerned with whether leadership decapitation strategies increase or decrease civil war insurgencies or the actions of terrorist groups. Our study expands our understanding of selective repression to include the effects of targeted arrest policies as a means to 
eliminate opposition leaders and ultimately derail the momentum of protest actions around nonviolent resistance campaigns.

A second implication is that targeted arrests is, as Earl (2005) argues, a distinct form of repression that should not be included in an overall measure of repression that includes violent tactics. Earl (2005) maintains that the negative effects of arrests are frequently underestimated because we fail to understand the significant physical, emotional, legal and economic costs incurred by activists. At the social movement level, arrests can reduce the viability of sustained anti-government mobilization by reducing the number of participants that can turnout, draining the movement of important leaders, and diminishing the morale of movement participants who suddenly perceive that the costs of engaging in collective action may be too high. Clearly, arrests are not commensurate with other forms of violent repression.

A third implication of our study is the relevance of our findings for the strategic incapacitation model of protest policing. Selective repression that involves surveillance for intelligence gathering, the denial and/or removal of public space for protesters, and the arrests of protest activists appears to be a viable strategy, especially if challengers are weakly organized. Related to this last point, challengers should be aware of their vulnerabilities to repressive strategies that can weaken their support networks and eliminate their leaders. They must be prepared to meet the burden of replenishing their leadership ranks. They also need to be vigilant about expanding their support into the political base of the governing elite in order to increase their bargaining leverage vis-à-vis the government.

Lastly, this study shows that fine-grained subnational data are particularly useful for understanding the evolutionary dynamics of repression and protest. In particular, we gain a more nuanced understanding of how repression changes and influences the course of a nonviolent resistance campaign. 


\section{ENDNOTES:}

${ }^{1}$ This definition is distinct from the broader categories of "strategic violence, nonviolent struggle or civil resistance (Chenoweth et al. 2017).

${ }^{2}$ See Honari (2018) for the most recent discussion of these research findings.

${ }^{3}$ There is also a "timing" approach in which scholars have made distinctions between "preemptive" and "reactive" repression. Reactive or situational repression refers to the state's actions to suppress challengers who are already mobilized in substantial numbers against the regime (Koopmans, 1997; Hafez 2003). However, there is a problem of conceptual conflation with preemptive and reactive repression, largely due to our inability to distinguish whether state's actions can be clearly identified as one or the other during an ongoing nonviolent resistance campaign.

${ }^{4}$ Past research that could potentially be relevant to selective repression, unfortunately, reverses the causal arrow by investigating whether certain levels and forms of protest influence the types of policing strategies that are used (see Earl and Soule 2006 for examples).

${ }^{5}$ Earl and Soule (2010) investigate different types of protest policing between 1960 and 1990 in New York City but the protest policing most closely associated with selective repression is the "legal eagle" strategy where police controlled and/or repressed a protest event exclusively through arrests. They found that this strategy was associated with declines in protests in both the short and medium term. However, the arrests occurred in the context of ongoing protests which makes it harder to discern whether the arrests were targeting individuals selectively or randomly rounding up protesters.

${ }^{6}$ Although the strategic incapacitation model has appeared as a government strategy for policing large scale demonstrations after $9 / 11$, there is no systematic empirical evidence about how frequently it appears across large scale demonstrations in the United States since 2001 or under what conditions it is likely to appear in some cases but not others.

${ }^{7}$ Leaders who were arrested during protests and who did not face jail time were excluded from the sample. ${ }^{8}$ We realize that there is a range of repressive tactics that go beyond the use of coercive weapons. For instance, Smithey and Kurtz $(2018 b, 191)$ refer to a fuller range of repression that involves intimidation (e.g. surveillance and harassment), manipulation (e.g. cooptation, disinformation, and censorship), soft repression (e.g. stigmatization, defamation, and arranged counter-demonstrations) but they are not included in our policing strategy of indiscriminate repression.

${ }^{9}$ Smithey and Kurtz (2018a) and Honari (2018) provide an excellent overview of this research.

${ }^{10}$ This backfire outcome has also been referred to as a "boomerang effect", political jiu-jitsu, blowback and backlash effects (Chenoweth et al. 2017).

${ }^{11}$ There are other causal mechanisms besides these two, although moral outrage and communication networks are the most prominent ones. For instance, in the Gezi protest campaign, Anisin (2016a) maintains that spontaneity and the nonhierarchical organization of the dissenters also helped to spur on different types of collective action during the backfire outcome. Över and Taraktaş' (2017) survey of Gezi participants reveals that boundary deactivation was a crucial causal mechanism for the backfire outcome. In other words, the shared personal experience of repression during the Gezi campaign led to greater solidarity among the dissenters which fueled their collective action. This boundary deactivation mechanism linked disparate and diverse dissenters together as they opposed the regime.

${ }^{12}$ On the other hand, our study does not model all of the factors that could affect the mobilizational levels in the Gezi campaign (e.g., political opportunities, resources, backfire and framing). Instead, we focus on the reasons that different forms of repression influenced the rate of protest actions alone. In short, we do not aim to provide a comprehensive explanation of the overall mobilization behavior in the campaign.

${ }^{13}$ The codebook is available as an online supplement on the journal's website.

${ }^{14}$ Dissidents innovated the standing man protests and park forums after the police cleared the park on June 15. The "standing man" protests involved protesters standing quietly, while "forums" involved public meetings among activists who discussed ways to institutionalize the movement or to share information about legal strategies in the event of an arrest (Gürcan and Peker 2015, 109-110). 
${ }^{15}$ Offsite targeted arrests were the main form of selective repression that Turkish authorities relied on. In addition, our arrest data originates from newspaper reports rather than official sources. Given the semi-authoritarian nature of the Turkish government, we acknowledge that our arrest data could be underreported, thus limiting empirical findings of our study.

${ }^{16} \mathrm{~A}$ logit transformation $(\ln [\mathrm{y} / 1-\mathrm{y}])$ is useful when the dependent variable is a proportion and is bounded by 0 and 1. The transformation smooths the variable and fits it on a real line (Papke and Wooldridge 1996). To avoid missing values (due to $y=0$ or $y=1$ ), we added .01 to the variable.

${ }^{17}$ Given the strong theoretical indications of the directions of the effects of our variables, one-tailed tests are appropriate for our analysis.

${ }^{18}$ We ruled out multicollinearity as a potential explanation for this negative result as there was no significant correlation between foreign support and any of the other independent variables. Pearson's correlation coefficients between foreign support and targeted arrests, indiscriminate repression, and accommodation are $-0.28,0.43$, and 0.54 respectively. 


\section{REFERENCES}

Amnesty International. 2013. Gezi Park Protests: Brutal Denial of the Right to Peaceful Assembly in Turkey. London, UK: Amnesty International.

Anisin, Alexei. 2016a. "Repression, Spontaneity, and Collective Action: the 2013 Turkish Gezi Protests." Journal of Civil Society 12 (4):411-429.

---. 2016b. "Violence begets violence: Why states should not lethally repress popular protest." The International Journal of Human Rights 20 (7):893-913.

Atak, Kıvanç. 2017. "Encouraging Coercive Control: Militarisation and Classical Crowd Theory in Turkish Protest Policing." Policing and Society 27 (7):693-711.

Atak, Kıvanç, and Donatella della Porta. 2016. "Popular Uprisings in Turkey: Police Culpability and Constraints on Dialogue-oriented Policing in Gezi Park and Beyond." European Journal of Criminology 13 (5):610-625.

Aytaç, S. Erdem, Luis Schiumerini, and Susan Stokes. 2017. "Protests and Repression in New Democracies." Perspectives on Politics 15 (1):62-82.

---. 2018. "Why Do People Join Backlash Protests? Lessons from Turkey." Journal of Conflict Resolution 62 (6):1205-1228.

Bob, Clifford, and Sharon Erickson Nepstad. 2007. "Kill a Leader, Murder a Movement? Leadership and Assassination in Social Movements." American Behavioral Scientist 50 (10):1370-1394.

Box, George EP and George C Tiao. 1975. "Intervention Analysis with Applications to Economic and Environmental Problems." Journal of the American Statistical Association 70(349):70-79.

Boykoff, Jules. 2007. "Limiting Dissent: The Mechanisms of State Repression in the USA " Social Movement Studies 6 (3):281-310.

Brandt, Patrick T., and John T. Williams. 2001. "A Linear Poisson Autoregressive Model: The Poisson AR(p) Model." Political Analysis 9 (2):164-184.

Brockett, Charles D. 1995. "A Protest-Cycle Resolution of the Repression/Popular-Protest Paradox " In Repertoires and Cycles of Collective Action, edited by Mark Traugott. Durham: Duke University Press.

Budak, Ceren, and Duncan J. Watts. 2015. "Dissecting the Spirit of Gezi: Influence vs. Selection in the Occupy Gezi Movement." Sociological Science 2:370-397.

Chenoweth, Erica. 2018. "Backfire in Action: Insights from Nonviolent Campaigns, 1946-2006." In The Paradox of Repression and Nonviolent Movements, edited by Lester R. Kurtz and Lee Smithey, 26-51. Syracuse, New York: Syracuse University Press.

Chenoweth, Erica, Evan Perkoski, and Sooyeon Kang. 2017. "State Repression and Nonviolent Resistance." Journal of Conflict Resolution 61 (9):1950-1969.

Chenoweth, Erica, and Maria J. Stephan. 2011. Why Civil Resistance Works : The Strategic Logic of Nonviolent Conflict. New York: Columbia University Press.

Cunningham, David. 2003. "The Patterning of Repression: FBI Counterintelligence and the New Left." Social Forces 82 (1):209-240.

Davenport, Christian. 2007. "State Repression and Political Order." Annual Review of Political Science 10:1-23. 
---. 2015. How Social Movements Die. New York: Cambridge University Press.

Davenport, Christian, and Molly Inman. 2012. "The State of State Repression Research Since the 1990s." Terrorism and Political Violence 24 (4):619-634.

Davenport, Christian, Hank Johnston, and Carol McClurg Mueller. 2005. Repression and Mobilization, Social movements, protest, and contention. Minneapolis: University of Minnesota Press.

della Porta, Donatella. 1996. "Social Movements and the State: Thoughts on the Policing of Protests." In Comparative Perspectives on Social Movements: Political Opportunities, Mobilizing Structurs, and Cultural Framings, edited by Doug McAdam, John D. McCarthy and Mayer N. Zald, 62-92. New York: Cambridge University Press.

---. 2013. Can Democracy be Saved? . Oxford, UK: Polity Press.

della Porta, Donatella, and Herbert Reiter. 1998. Policing Protest: The Control of Mass Demonstrations in Western Democracies. . Minneapolis: : University of Minnesota Press. della Porta, Donatella, and Sidney Tarrow. 2012. "Interactive Diffusion:The Coevolution of Police and Protest Behavior With an Application to Transnational Contention." Comparative Political Studies 45 (1):119-152.

DeNardo, James. 1985. Power in Numbers: The Political Strategy of Protest and Rebellion. Princeton, N.J.: Princeton University Press.

Dugan, Laura, and Erica Chenoweth. 2012. "Moving Beyond Deterrence: The Effectiveness of Raising the Expected Utility of Abstaining from Terrorism in Israel." American Sociological Review 77 (4):597-624.

Earl, Jennifer. 2003. "Tanks, Tear Gas, and Taxes: Toward a Theory of Movement Repression." Sociological Theory 21 (1):44-68.

---. 2005. "“You Can Beat the Rap, But You Can't Beat the Ride:" Bringing Arrests Back into Research on Repression." In Research in Social Movements, Conflicts and Change, 101139.

Earl, Jennifer, and Sarah Soule. 2006. "Seeing Blue: A Police-Centered Explanation of Protest Policing." Mobilization: An International Quarterly 11 (2):145-164.

Earl, Jennifer, and Sarah A Soule. 2010. "The Impacts of Repression: The Effect of Police Presence and Action on Subsequent Protest Rates." Research in Social Movements, Conflicts, and Change 30:75-113.

Earl, Jennifer, Sarah A. Soule, and John D. McCarthy. 2003. "Protest under Fire? Explaining the Policing of Protest." American Sociological Review 68 (4):581-606.

Francisco, Ronald A. 2004. "After the Massacre: Mobilization in the Wake of Harsh Repression." Mobilization: An International Quarterly 9 (2):107-126.

Gillham, Patrick F. 2011. "Securitizing America: Strategic Incapacitation and the Policing of Protest Since the 11 September 2001 Terrorist Attacks." Sociology Compass 5 (7):636652. doi: 10.1111/j.1751-9020.2011.00394.x.

Gillham, Patrick F., Bob Edwards, and John A. Noakes. 2013. "Strategic Incapacitation and the Policing of Occupy Wall Street Protests in New York City, 2011." Policing and Society 23 (1):81-102. doi: 10.1080/10439463.2012.727607.

Gillham, Patrick, and John Noakes. 2007. "'More Than A March in a Circle": Transgressive Protests and the Limits of Negotiated Management." Mobilization: An International Quarterly 12 (4):341-357. doi: 10.17813/maiq.12.4.j10822802t7n0t34. 
Granovetter, Mark. 1978. "Threshold Models of Collective Behavior." The American Journal of Sociology 83 (6):1420-1443.

Grimm, Jannis, and Cilja Harders. 2018. "Unpacking the Effects of Repression: The Evolution of Islamist Repertoires of Contention in Egypt after the Fall of President Morsi." Social Movement Studies 17 (1):1-18.

Gürcan, Efe Can, and Efe Peker. 2015. Challenging Neoliberalism at Turkey's Gezi Park. New York: Palgrave MacMillan.

Hafez, Mohammed M. 2003. Why Muslims Rebel: Rrepression and Resistance in the Islamic World. Boulder, Colo.: Lynne Rienner Publishers.

Hess, David, and Brian Martin. 2006. "Repression, Backfire, and the Theory of Transformative Events." Mobilization 11 (2):249-67.

Honari, Ali. 2018. "From 'The Effect of Repression' toward 'The Response to Repression'." Current Sociology 66 (6):950-973.

Jasper, James M. 1997. The Art of Moral Protest: Culture, Biography, and Ceativity in Social Movements. Chicago: University of Chicago Press.

---. 2014. "Constructing Indignation: Anger Dynamics in Protest Movements." Emotion Review 6 (3):208-13.

Johnson, Daniel. 2015. "'Workers in the New Turkey"." accessed January 19. https://www.jacobinmag.com/2015/04/turkey-workers-strike-mine-explosion.

Jordan, Jenna. 2009. "When Heads Roll: Assessing the Effectiveness of Leadership Decapitation." Security Studies 18 (4):719-755.

Kalyvas, Stathis N. 2006. The Logic of Violence in Civil War, Cambridge studies in comparative politics. Cambridge; New York: Cambridge University Press.

Keck, Margaret E., and Kathryn Sikkink. 1998. Activists Beyond Borders: Advocacy Networks in International Politics. Ithaca, N.Y.: Cornell University Press.

Koopmans, Ruud. 1997. "Dynamics of Repression and Mobilization: The German Extreme Right in the 1990s." Mobilization 2 (2):149-165.

Krain, Matthew. 2000. Repression and Accommodation in Post-Revolutionary States. 1st ed. New York: St. Martin's Press.

Kuran, Timur. 1991. "Now Out of Never: The Element of Surprise in the East European Revolution of 1989." World Politics 44 (1):7-48.

Lichbach, Mark Irving. 1987. "Deterrence of Escalation? The Puzzle of Aggregate Studies of Repression and Dissent." Journal of Conflict Resolution 31 (2):266-97.

---. 1998. The Rebel's Dilemma. Ann Arbor: University of Michigan Press.

Lindekilde, Lasse. 2014. "A Typology of Backfire Mechanisms." In Dynamics of Political Violence: A Process-Oriented Perspective on Radicalization and the Escalation of Political Conflict, edited by Lorenzo Bosi, Charles Demetriou and Stefan Malthaner, 51-70. Surrey, England: Ashgate Publishing Limited.

Lohmann, Susanne. 1994. "The Dynamics of Informational Cascades: The Monday Demonstrations in Leipzig, East German, 1989-91." World Politics 47 (October):42-101.

Lyall, Jason. 2009. "Does Indiscriminate Violence Incite Insurgent Attacks?: Evidence from Chechnya." Journal of Conflict Resolution 53 (3):331-362.

Martin, Brian. 2007. Justice Ignited: The Dynamics of Backfire. Lanham Md.: Rowman \& Littlefield Pub. 
Mason, T. David, and Dale A. Krane. 1989. "The Political Economy of Death Squads: Toward a Theory of the Impact of State-Sanctioned Terror." International Studies Quarterly 33 (2):175-198.

McPhail, Clark, and John D. McCarthy. 2005. "Protests, Protest Repression, and Their Interaction." In Repression and Mobilization, edited by Christian Davenport, Hank Johnston and Carol McClurg Mueller. Minneapolis: University of Minnesota Press.

Moore, Will H., and Ronny Lindstrom. 1996. The Violent Intranational Conflict Data Project (VICDP) Codebook. Department of Political Science, University of California - Riverside.

Murdie, Amanda, and Tavishi Bhasin. 2011. "Aiding and Abetting: Human Rights INGOs and Domestic Protest." The Journal of Conflict Resolution 55 (2):163-191.

Nepstad, Sharon Erickson. 2011. Nonviolent Revolutions: Civil Resistance in the late 20th Century, Oxford Studies in Culture and Politics. Oxford ; New York: Oxford University Press.

Noakes, John A., Brian V. Klocke, and Patrick F. Gillham. 2005. "Whose Streets? Police and Protester Struggles over Space in Washington, DC, 29-30 September 2001." Policing and Society 15 (3):235-254. doi: 10.1080/10439460500168576.

Noakes, John, and Patrick Gillham. 2006. "Aspects of the 'New Penology' in the Police Response to Major Political Protests in the United States, 1999-2000." In The Policing of Transnational Protests, edited by Donatella della Porta, Abby Peterson and Herbert Reiter, 97-115. Aldershot: Ashgate Publishing.

O'Brien, Kevin J., and Yanhua Deng. 2015. "Repression Backfires: Tactical Radicalization and Protest Spectacle in Rural China." Journal of Contemporary China 24 (93):457-470.

Odabaş, Meltem, and Heidi Reynolds-Stenson. 2018. "Tweeting from Gezi Park: Social Media and Repression Backfire." Social Currents 5 (4):386-406.

Opp, Karl-Dieter. 1994. "Repression and Revolutionary Action: East Germany in 1989." Rationality and Society 6 (1):101-138.

Ortiz, David. 2007. "Confronting Oppression with Violence: Inequality, Military Infrastructure and Dissident Repression." Mobilization: An International Quarterly 12 (3):219-238.

Över, Defne, and Başak Taraktaş. 2017. "When Does Repression Trigger Mass Protest? The 2013 Gezi Protests." In Non-State Violent Actors and Social Movement Organizations, 205239.

Özen, Hayriye. 2015. "An Unfinished Grassroots Populism: The Gezi Park Protests in Turkey and Their Aftermath." South European Society and Politics 20 (4):533-552.

Öztürkcan, Selcen, Nihat Kasap, Müge Çevik, and Tauhid Zaman. 2017. "An Analysis of the Gezi Park Social Movement Tweets." Aslib Journal of Information Management 69 (4):426440.

Papke, Leslie E., and Jeffrey M. Wooldridge. 1996. "Econometric Methods for Fractional Response Variables With an Application to 401 (K) Plan Participation Rates." Journal of Applied Econometrics 11 (6):619-632.

Pearlman, Wendy. 2013. "Emotions and the Microfoundations of the Arab Uprisings." Perspectives on Politics 11 (2):387-409.

Piven, Frances Fox, and Richard A. Cloward. 1977. Poor People's Movements: Why They Suceed, How They Fail. New York: Pantheon Books. 
Rogers, Joshua. 2011. Shooting Citizens - Saving Regimes? In Working Paper No.3, Center for North African and Middle Eastern Politics, Freie Universitat, December. Berlin.

Schock, Kurt. 2005. Unarmed Insurrections: People Power Movements in Nondemocracies. Minneapolis, MN: University of Minnesota Press.

Simmons, Noah Nathan 2012. "Effects of Leadership Decapitation on Social Movements, $1960-$ 1995. ." Honor's Thesis, Schreyer Honors College under the auspices of Political Science and Global and International Studies,, Pennsylvania State University. .

Smithey, Lee A., and Lester R. Kurtz. 2018a. "Introduction." In The Paradox of Repression and Nonviolent Movements, edited by Lester R. Kurtz and Lee A. Smithey, 1-25. Syracuse, New York: Syracuse University Press.

---. 2018b. "'Smart" Repression." In The Paradox of Repression and Nonviolent Movements, edited by Lester R. Kurtz and Lee A. Smithey, 185-214. Syracuse, New York: Syracuse University Press.

Starr, Amory, Luis A. Fernandez, and Christian Scholl. 2011. Shutting Down the Streets: Political Violence and Social Control in the Global Era. New York: New York University Press.

Sullivan, Christopher Michael. 2016a. "Political Repression and the Destruction of Dissident Organizations: Evidence from the Archives of the Guatemalan National Police." World Politics 68 (4):645-676.

---. 2016b. "Undermining Resistance Mobilization, Repression, and the Enforcement of Political Order." Journal of Conflict Resolution 60 (7):1163-1190.

Sullivan, Christopher Michael, and Christian Davenport. 2017. "The Rebel Alliance Strikes Back: Understanding the Politics of Backlash Mobilization." Mobilization: An International Quarterly 22 (1):39-56.

Tarrow, Sidney G. 1989. Democracy and Disorder: Protest and Politics in Italy, 1965-1975. Oxford: Oxford University Press.

Tufekci, Zeynep. 2017. Twitter and Tear Gas: The Power and Fragility of Networked Protest: Yale University Press.

van Leeuwen, Marco H.D., John D. McCarthy, Jacquelien van Stekelenburg, and Bert Klandermans. 2015. "To What Extent hasTtransnational Protest Policing Diffused to National European Protest Events?" Political Psychology Conference, 2015.

van Stekelenburg, Jacquelien, and Bert Klandermans. 2013. "The Social Psychology of Potest." Current Sociology 61 (5-6):886-905.

van Zomeren, Martijn. 2013. "Four Core Social-Psychological Motivations to Undertake Collective Action." Social and Personality Psychology Compass 7 (6):378-388.

White, Robert W. 1989. "From Peaceful Protest to Guerrilla War: Micromobilization of the Provisional Irish Republican Army." The American Journal of Sociology 94 (6):1277-1302. 


\section{TABLES AND FIGURES}

TABLE 1: Poisson Autoregressive Estimates of Protest Rates during the Gezi Protest Campaign

\begin{tabular}{|c|c|c|}
\hline Variable & Model 1 & Model 2 \\
\hline Targeted Arrests & $\begin{array}{l}-0.154^{*} \\
(0.079)\end{array}$ & $\begin{array}{l}-0.131 * \\
(0.072)\end{array}$ \\
\hline Indiscriminate Repression & $\begin{array}{l}0.046 * * \\
(0.009)\end{array}$ & $\begin{array}{c}0.058 * * \\
(0.010)\end{array}$ \\
\hline Concessions & - & $\begin{array}{l}-0.021 \\
(0.152)\end{array}$ \\
\hline Foreign Support to Protesters & - & $\begin{array}{l}-0.134 \\
(0.088)\end{array}$ \\
\hline Constant & $\begin{array}{l}1.716^{* *} \\
(0.151)\end{array}$ & $\begin{array}{l}1.723^{* *} \\
(0.153)\end{array}$ \\
\hline AR parameter 1 (lag one) & $\begin{array}{l}0.550 * * \\
(0.107)\end{array}$ & $\begin{array}{l}0.650 * * \\
(0.107)\end{array}$ \\
\hline $\mathrm{N}$ & 71 & 71 \\
\hline Probability>chi-square & - & - \\
\hline Adjusted $\mathrm{R}^{2}$ & 0.70 & 0.75 \\
\hline
\end{tabular}


FIGURE 1

A Comparison of the Frequency of Twitter and Protest Actions Data in the Gezi Park Nonviolent Resistance Campaign

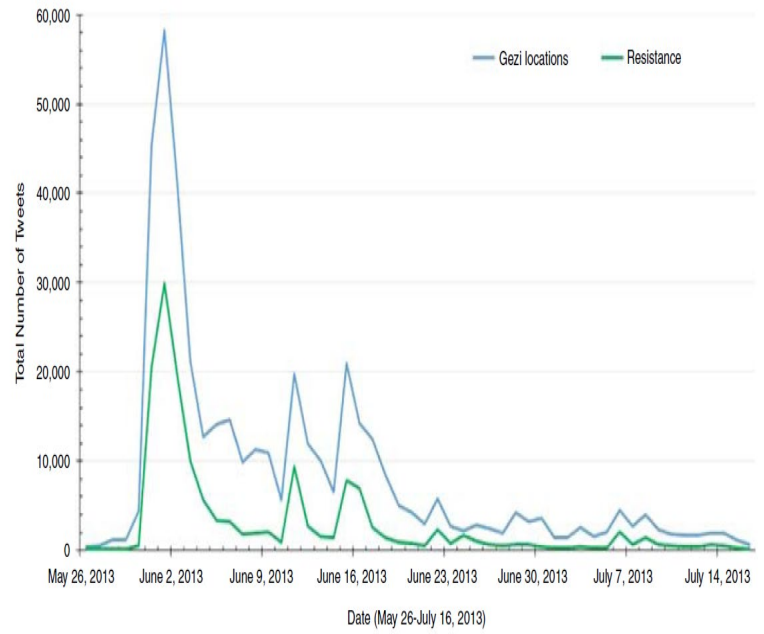

Ozturkcan et al. (2017; p 433)

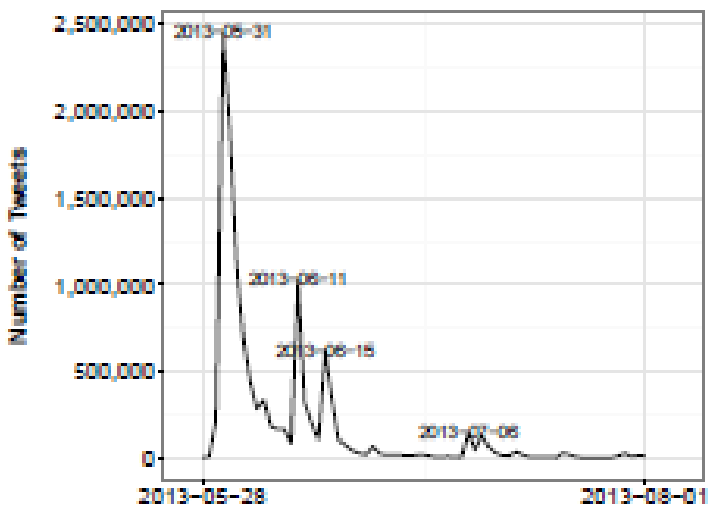

Budak and Watts (2015; p 376)

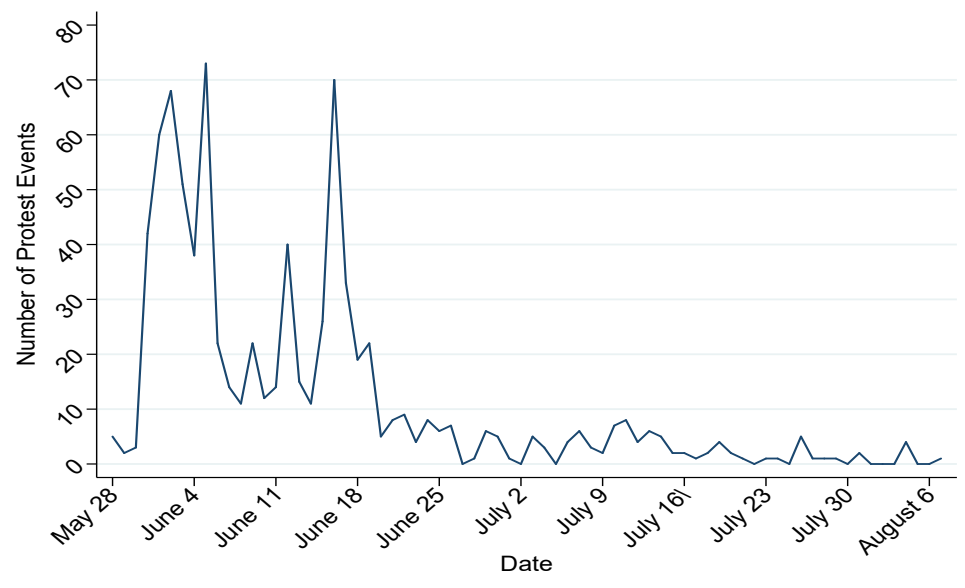

Author (2019) 
FIGURE 2

Time Series Plots of Offsite Targeted Arrests as a Proportion of Total Arrests (Plot A) and the Total Number of Offsite Targeted Arrests (Plot B) in the Gezi Park Nonviolent Resistance Campaign

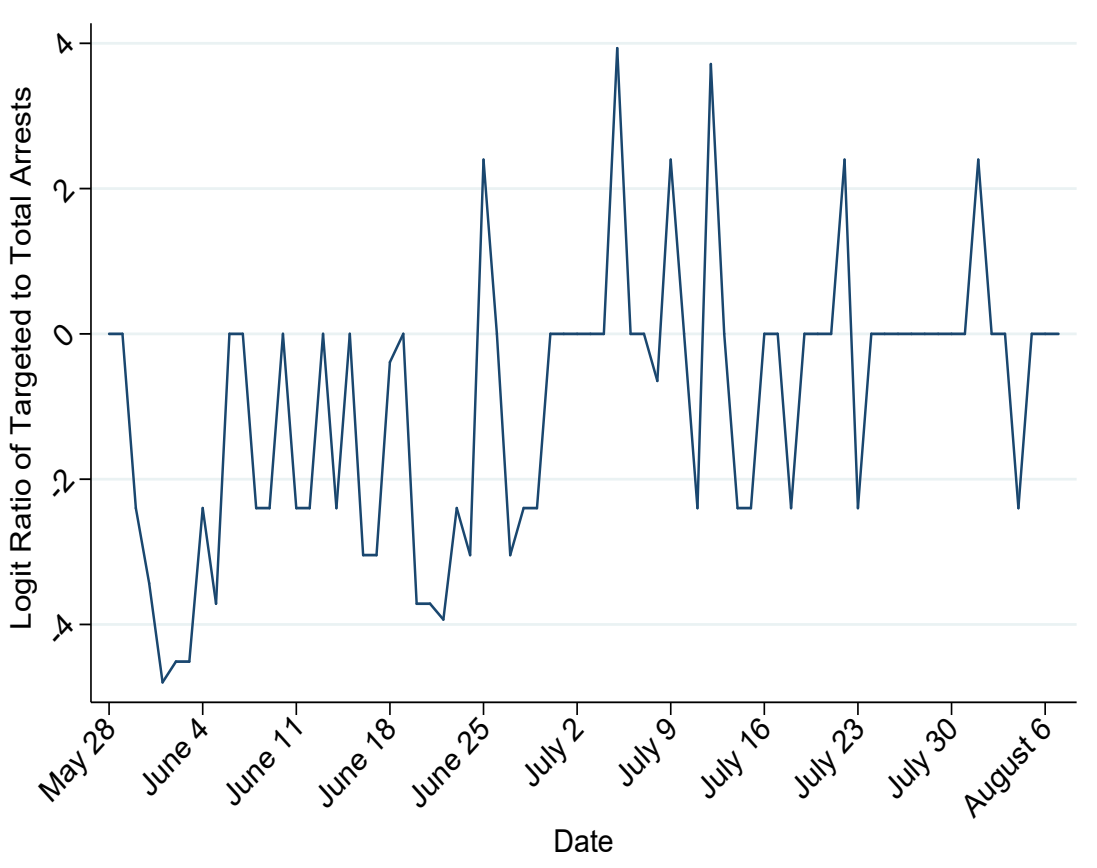

Plot A. Offsite Arrests/Total Arrests

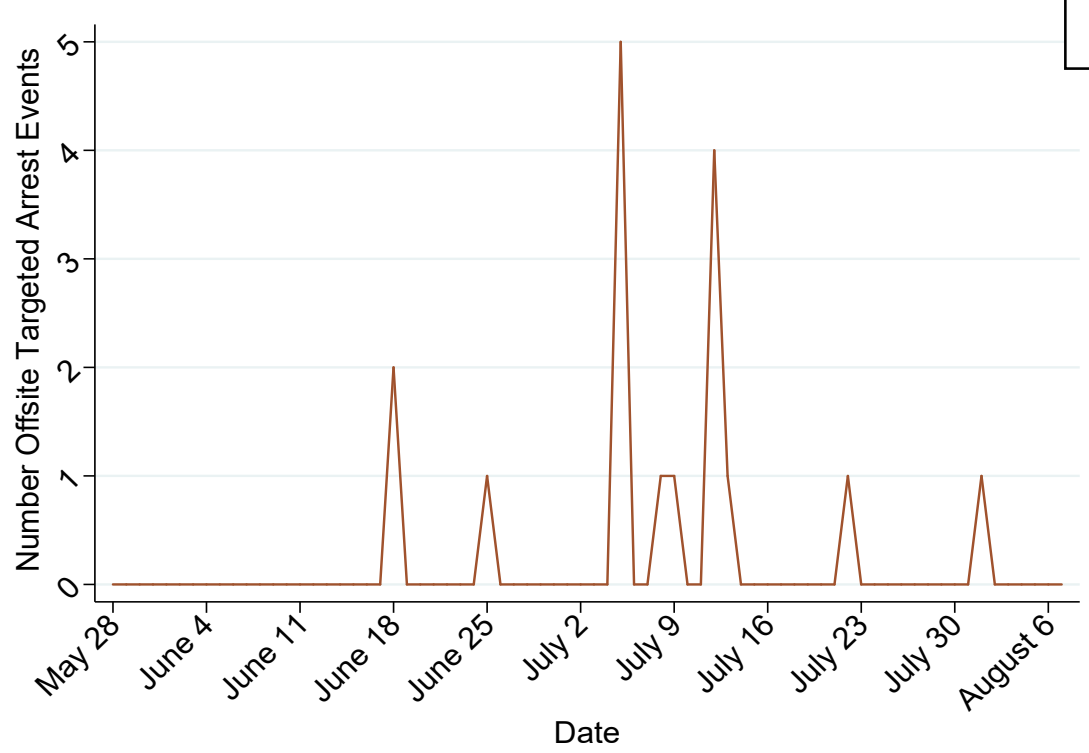

Plot B. Total No. of Offsite Targeted Arrests 
FIGURE 3

Autocorrelation Plot for Rate of Protest Actions

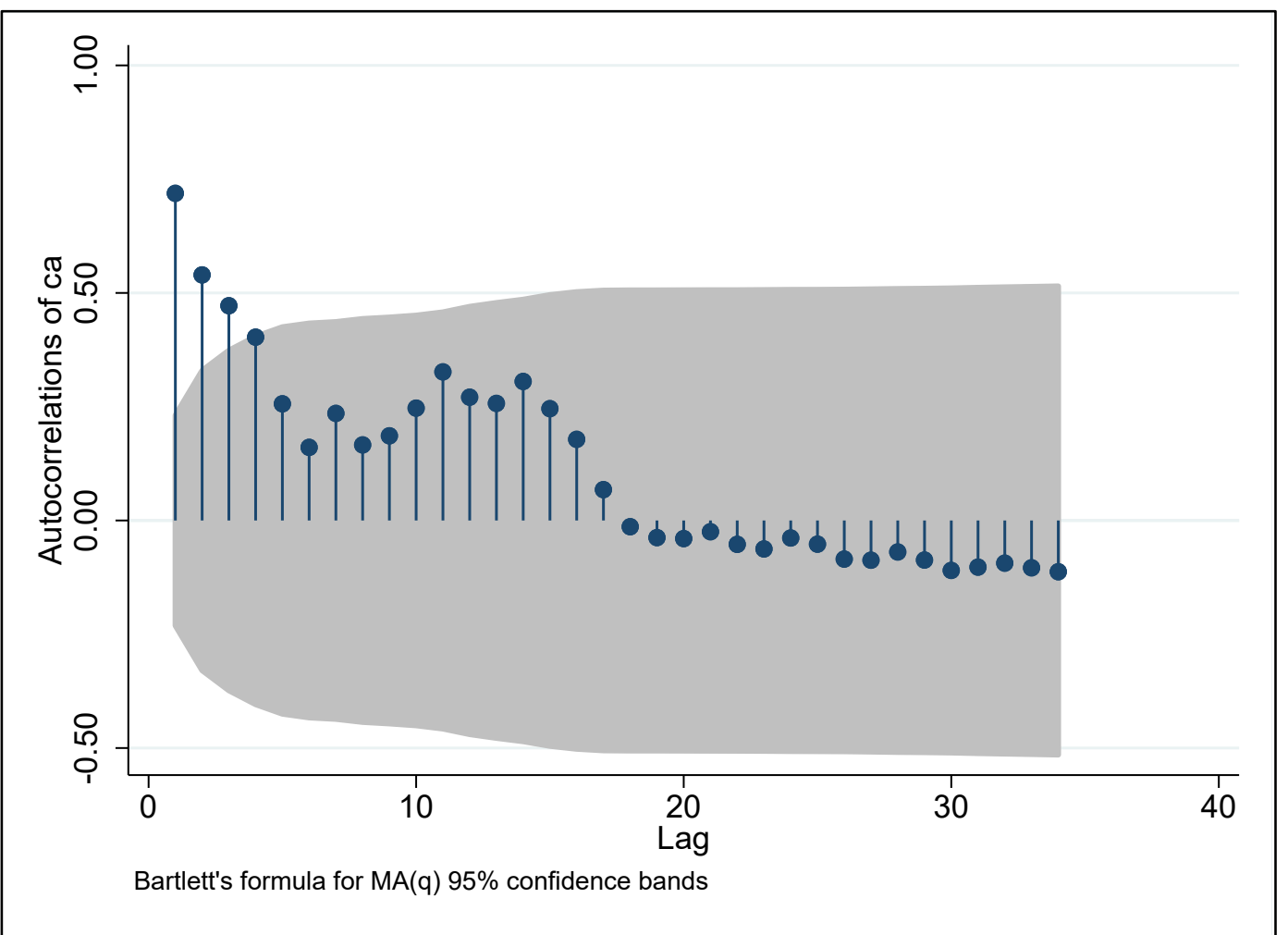




\section{APPENDIX A: PLOTS OF THE CONTROL VARIABLES}

Figure A-1: Targeted Arrests and Concessions During the Gezi Campaign May-August 2013

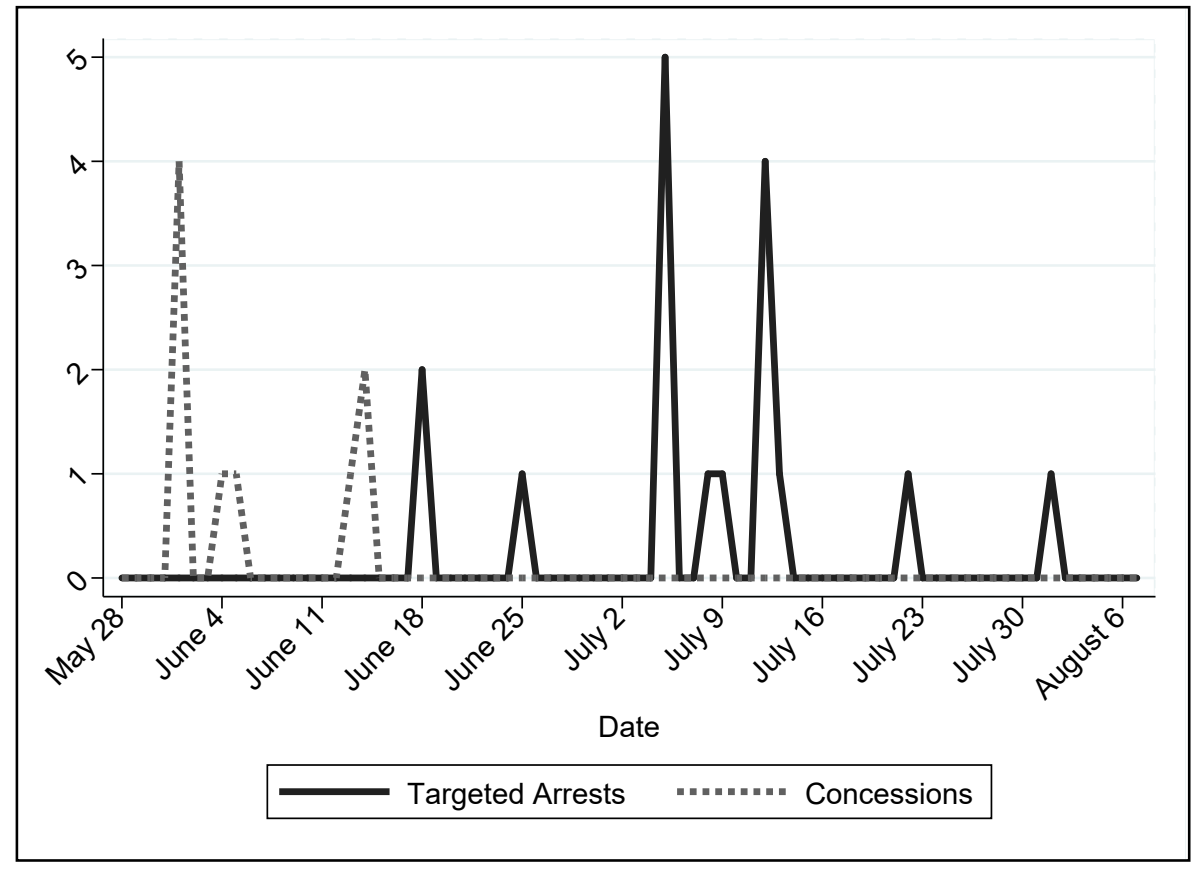

Figure A-2: Targeted Arrests and Foreign Support to Protesters During the Gezi Campaign May-August 2013

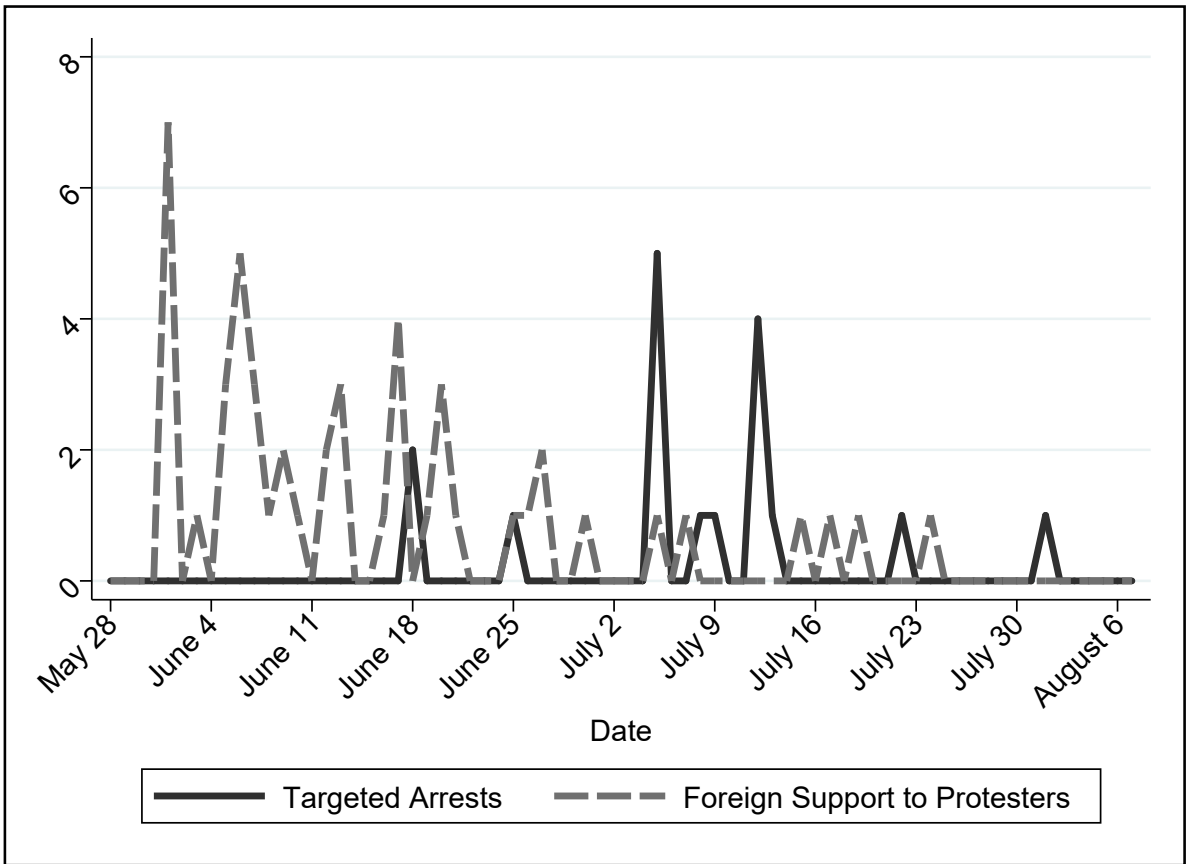




\section{APPENDIX B: ROBUSTNESS CHECKS}

Since the Turkish government's implementation of a targeted arrest strategy represents a sudden change in its tactics, we treat the switch to targeted arrests as an "intervention" (Box and Tiao 1975 ) to check the robustness of the negative effect of this variable. By running a single group time series analysis, we estimate the impact of targeted arrests (or the "intervention") on protest rates. In addition to a Poisson autoregressive (PAR) model of order ( $p$ ) as we did in the manuscript, we also estimate a Zero-Inflated Negative Binomial Regression (ZINB). We then use the ZINB model's estimates for forecasting purposes.

The operationalization of rate of protest actions, the dependent variable, and the indiscriminate repression variables remain the same as in the analysis in the main manuscript. However, to run an intervention model, we construct a time variable, which denotes the number of days from the start of the Gezi campaign until its end. The coefficient of time represents the trajectory of protest activity until the government implements the targeted arrest strategy. Targeted arrest strategy, the key independent variable, is a binary variable, coded 1 for the days when the strategy is implemented. As Figure 2 illustrates, the government began using targeted arrests on June 18 until the end of the campaign. Thus, this variable is coded 1 for the days between June 18 and August 7, 2013; and 0 otherwise. The coefficient of targeted arrests is the intercept at the time when the government began using this strategy and indicates any changes in protest activity after its implementation. A significant negative coefficient for targeted arrest would signify a sudden decline in protest activity. Finally, we add an interaction variable for the combined effects of targeted and indiscriminate effects after the implementation of targeted arrests.

\section{Findings}

Table B-1 shows the results of the ZINB and PAR (1) for the protest activity during the Gezi campaign. The analysis suggests that the rate of protest actions decreased significantly after the Turkish government responded to the dissidents' tactical innovations with a targeted arrest strategy on June 18, 2013. Indiscriminate repression increases protest activity significantly in the PAR ( $p<.001)$ and the ZINB $(p<.001)$ models. Targeted arrest, the intervention variable, has a negative and statistically significant coefficient both in the PAR and ZINB analyses ( $p<.01$ and $p<.05$, respectively), confirming our findings in the main manuscript. The interaction variable for indiscriminate and discriminate repression, which represents, is not significant in either model. Therefore, the decrease in the rate of protest action is clearly a function of targeted arrest. 
TABLE B-1 ZINB and PAR Estimates of Protest Activity during the Gezi Protest Campaign

\begin{tabular}{lcc}
\hline \multicolumn{1}{c}{ Variable } & PAR & ZINB \\
\hline Time & -0.016 & $-0.026^{* *}$ \\
& $(0.010)$ & $(0.009)$ \\
Intervention & $-1.380^{* *}$ & $-0.773^{*}$ \\
(Targeted Arrests) & $(0.447)$ & $(0.386)$ \\
Indiscriminate Repression & $0.033^{* *}$ & $0.050^{* *}$ \\
& $(0.006)$ & $(0.015)$ \\
Targeted Arrests $x$ & $0.001^{*}$ & 0.050 \\
Indiscriminate Repression & $(0.022)$ & $(0.041)$ \\
& & \\
Constant & $3.120^{* *}$ & $2.896^{* *}$ \\
& $(0.041)$ & $(0.258)$ \\
AR parameter 1 (lag one) & 0.169 & - \\
& $(0.121)$ & 72 \\
\hline $\mathrm{N}$ & 71 & 0.000 \\
Probability>chi-square & - & - \\
Adjusted $\mathrm{R}^{2}$ & 0.72 & \\
\hline * $p<.05, * * 001 ;$ All significance tests are one-tailed, standard errors in parentheses &
\end{tabular}

Table B-2 illustrates the factor changes based on the ZINB analysis in the rate of protest actions for a clear interpretation of the coefficients. Accordingly, the rate of protest actions decreases by a factor of 0.46 after the government implements targeted arrest, holding all else constant. Indiscriminate repression increases the rate of protest actions by a factor of 1.05 , confirming this strategy's escalatory effect on protests. 
TABLE B- 2 Factor Change in Expected Rate of Protest Activity

\begin{tabular}{lc} 
Variable & Factor Change \\
\hline Time & -0.98 \\
\hline $\begin{array}{l}\text { Intervention } \\
\text { (Targeted Arrests) }\end{array}$ & -0.46 \\
\hline & 1.05 \\
\hline
\end{tabular}

As the Predictive Margins plot generated based on the ZINB analysis demonstrate (Figure B-1), the predicted rate of protest actions declined steadily after the government switched strategies. While the rate of protest actions was slightly above 20 just after before the implementation of targeted arrests, rate goes down to 15 after about 12 days, and all the way down to 6 after about 7 weeks, indicating a more than $70 \%$ decrease in the rate of protest actions.

FIGURE B-1 Predicted Number of Events After Intervention (Targeted Arrests)

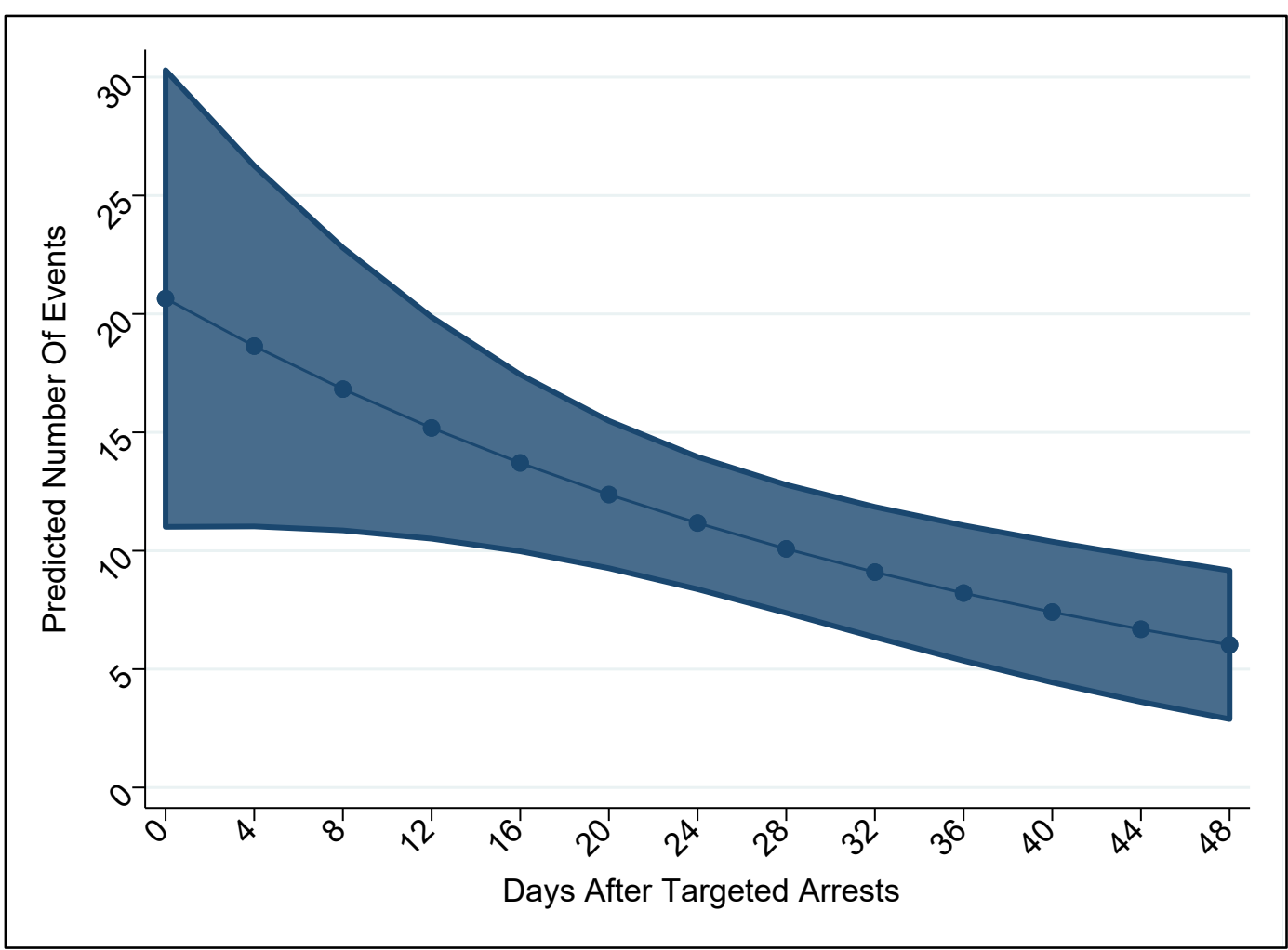


To run additional robustness checks on our findings, we use out-of-sample forecasting. Out-ofsample forecasting compares the predicted values generated by the model to the observed values. For our purposes, two scenarios would help rule out the two rival explanations. The first one is to generate predicted values for the time period after June 17, before the government implemented the targeted arrest strategy. The idea is that based on the observed values of the protest activity series until June 18 , the out-of-sample forecasting technique predicts what protest activity should look like after June 18, when the targeted arrest strategy was implemented. An increase in the predicted number of protest activity would suggest that the rate of protest actions was increasing or staying relatively constant when the government was using indiscriminate repression. In contrast, a decrease would indicate that the campaign was already declining due to other variables that are not accounted for in the model.

To obtain the out-of-sample forecast for this first scenario, we run the ZINB regression on protests by excluding the days after June 18. The plot in Figure B-2 illustrates the number of observed protest events and the out-of-sample predictions based on the model. The increasing trend in the outof-sample predictions show that the model predicts an escalation in the rate of protest actions based on the observations before targeted arrests. Therefore, the possibility of any alternative factors stifling protests can be ruled out.

FIGURE B-2 Out-of-sample Forecasts for Protest Activity Based on Observations before Targeted Arrests

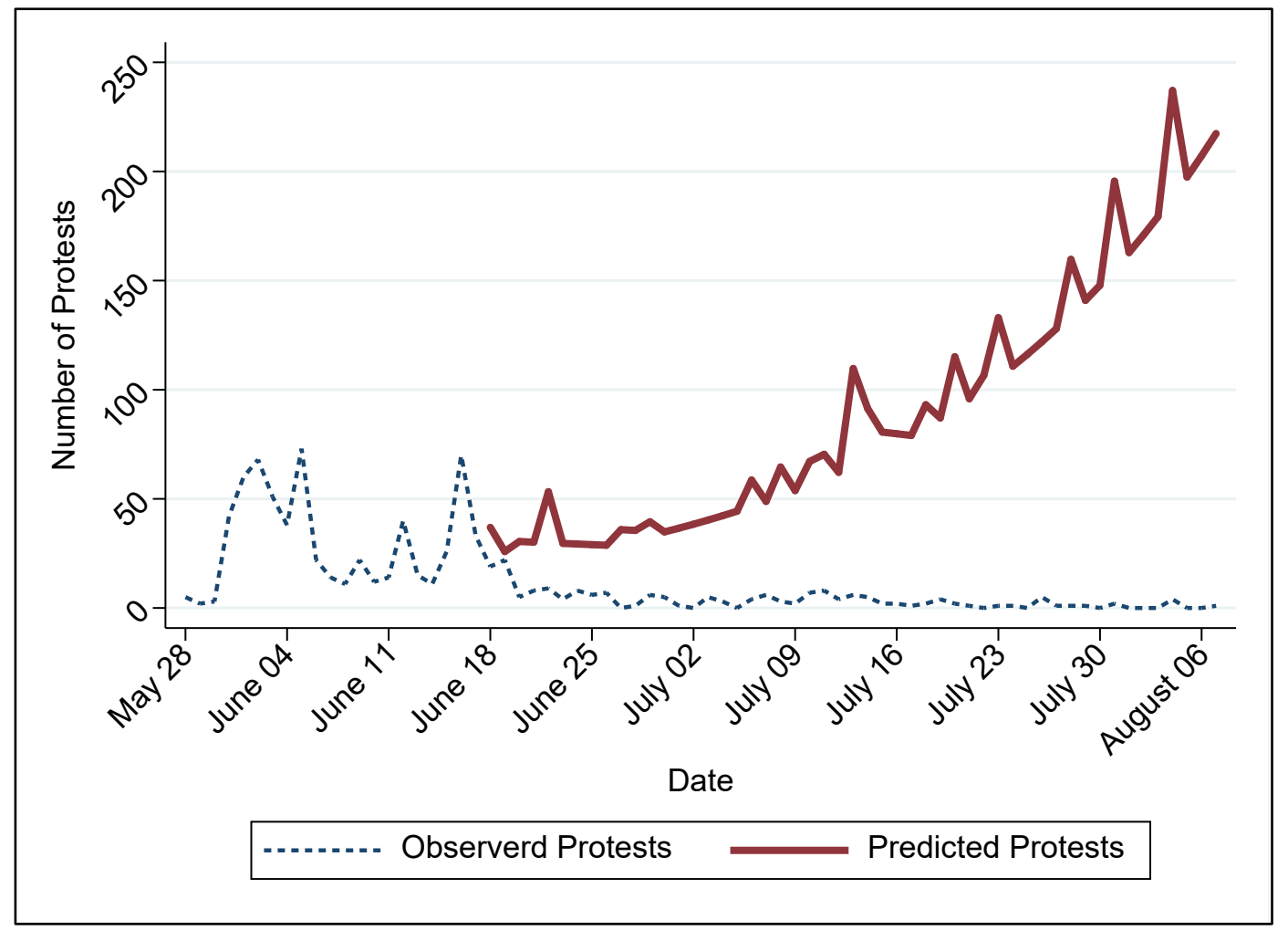


The second type of forecasting approach is to generate predicted values for a time period after the targeted arrest strategy had been implemented and note whether the predicted values for the rate of protest actions decreased after the government switched to targeted arrests as the observed values do. This scenario compares the observed values to the model's prediction after targeted arrests to assess how accurately the model predicts the rate of protest actions. A notable similarity between the trends of the predicted and observed values would demonstrate that even after a short time period after the targeted arrest strategy, the model captures the demobilizing effect of targeted arrest and predicts that the rate of protest actions declines significantly.

This time, we estimate the ZINB regression by excluding the days after June 30 . The plot for the number of observed protest events and the out-of-sample predictions for the remaining days in the campaign after June 30 in Figure B-3 demonstrates that the model predicts a significant decrease in the rate of protest actions confirming the negative effects of targeted arrests in our PAR models in the main manuscript.

FIGURE B-3 Out-of-sample Forecasts for Protest Activity Based on Observations after Targeted Arrests

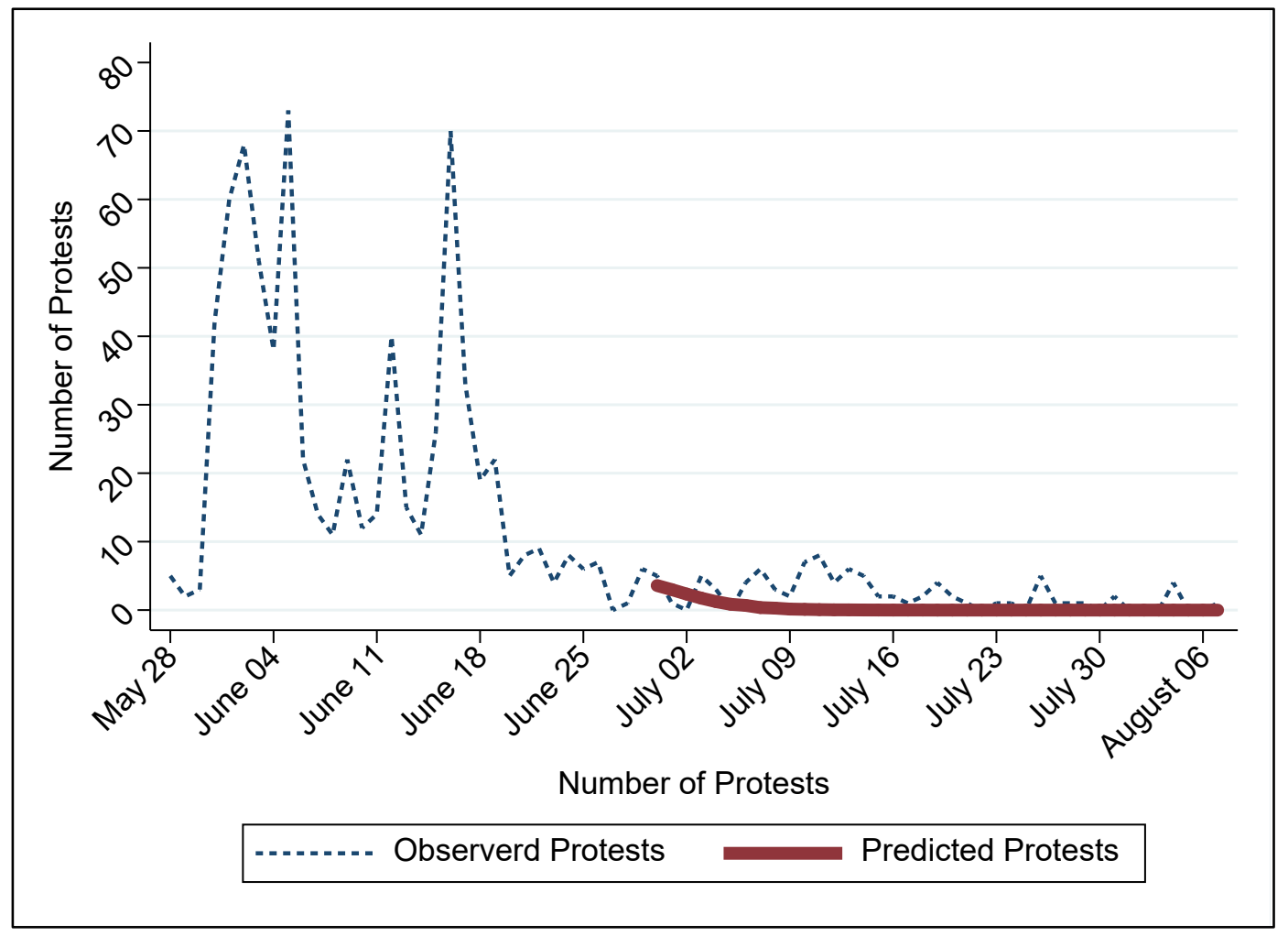


